\title{
CASE-LAW OF THE EUROPEAN COURT OF HUMAN RIGHTS AND THE EUROPEAN UNION LAW: AN AREA OF IMPORTANT INTERACTION AND DIALOGUE FOR STRONGER HUMAN RIGHTS PROTECTION IN EUROPE ${ }^{1}$
}

An overlap in the activities of the Council of Europe and the EU as regards the protection of human rights leads to cross-fertilisation of both systems. Commitment to human rights and the Convention is notably manifested in the on-going dialogue on accession of the EU to the European Convention on Human Rights. Ideally, interaction between the Council of Europe and the European Union should lead to construction of a uniform human rights constitutional legal space, built on the same principles of compliance with the rule of law and human rights, a destination that still remains on the horizon. The process of execution of judgments of the Strasbourg Court, which is a forward looking technical and non-political process, with potential political consequences, results in the transformation of the legal systems of the Council of Europe member states and thus assists them in bringing their legal systems closer to being compatible with the EU accession process. Thus, the strategic aim of the European integration and EU accession should be aligned with the Strasbourg judgment's implementation process, success in execution of judgments equalling to success in attainment of the Copenhagen accession criteria.

Keywords: Council of Europe, European Union, European Convention on Human Rights, European Court of Human rights, case-law, accession, European integration, execution of judgments, Copenhagen criteria.

\section{Introduction}

Council of Europe and European Union are two regional international organisations that are frequently seen as having an overlap in competences in the area of rule of law and human rights, democracy building and sustainable development. Even though European Union is largely seen as an organization focused on economic cooperation between its Member States, its competences in the areas of human rights, democracy and rule of law, the areas of "classical concern" for the Council of Europe, are rapidly expanding. One of the examples of such developments is the legal foundation for human rights protection in the EU is the Charter of Fundamental Rights of the European Union, which extensively relies on the European Convention of Human Rights and in essence on the Strasbourg

\footnotetext{
${ }^{1}$ All views expressed in this article are of personal nature and do not represent official views of the Council of Europe or the Department for the execution of judgments, where the author currently works. On the basis of presentation entitled "Judicial practice of EU and the Council of Europe in the area of human rights protection: influence on the administration of justice in Ukraine", made at the Scientific and practical conference "International experience on implementation and application of the EU-Ukraine Association agreement" (Kyiv), at the National University KyivMohyla Academy, 7 April 2020.

(C) Pavlo Pushkar, 2020
}

Court's case-law. Notably, Article 52 paragraph 3 of the Charter provides that the rights under the Charter correspond to the rights guaranteed for by the European Convention on Human Rights and their meaning should be the same as those laid down by the said Convention. At the same time, rights under the Charter can be essentially seen as more extensively covering "social rights" and can be said to be providing more extensive protection in some areas uncovered by the Convention, like in the areas of good governance, protection of environment or access to public information.

Institutional framework of the EU human rights protection is also rapidly developing, alongside the national protection mechanisms, with the enlargement of activities of the Fundamental Rights Agency, the European Court of Justice of the EU and the EU Commission. It goes without saying that case-law of the European Court of Justice in Luxembourg is, among many other areas, very much focused on fundamental rights and builds a strong legal foundation for the EU institutions compliance with the human rights standards. Such compliance should be effectuated in synchronicity with constitutional traditions common to the Member States, thus also de facto recognizing the 
principles of subsidiarity and margin of appreciation. These principles are also common to the European Convention on Human Rights, to the text of its Preamble and the constant jurisprudence of the Court reaffirming "the age of subsidiarity" for the Convention (Spano, 2014).

Rapid build-up and, in essence, expansion of the "human rights competences" of the EU institutions, especially after adoption of the Lisbon Treaty ${ }^{2}$, could be further manifested by the latest interaction of the EU institutions with Hungary and Poland on the issues related to rule of law, human rights compliance and the functioning of the democratic institutions. For instance, the judicial reform in Poland, with a suggested removal of judges under pretext of lowering their retirement age, raised issues of compliance with EU law under the Rule of Law Framework (European Commission, 2017). The main issues, therefore, that are being discussed with the Polish authorities focus on independence of the judiciary and irremovability of judges. Later on, the EU institutions, acting under the Rule of Law Framework, stated that the new disciplinary regime concerning judges in Poland undermined the judicial independence by not offering necessary guarantees to protect them from political control, as required by the Court of Justice of the European Union (Rule of Law, 2019). Similar issues, remain topical for a number of Eastern European states that are members to the Council of Europe in context of their Council of Europe statutory obligations, their obligations under the European Convention of Human Rights and, more specifically, in context of execution of judgments of the European Court of Human Rights. This specifically relates to cases pending execution concerning Hungary, Russian Federation, Portugal and Ukraine. ${ }^{3}$

Thus, it goes without saying that there is a sure overlap in the activities of these two international organisations as regards protection of human rights, there is definitely a dynamic of cross-fertilisation, mutual cooperation and interaction in the area, which is further confirmed not only by support that EU provides to the Council of Europe cooperation activities with its member-States, but also by a continued commitment of the European Union, also

2 The Lisbon Treaty increased the scope for European Union action in the areas of "traditional competence" of the Council of Europe: human rights, democracy and the rule of law. Additionally, EU is a party to 17 treaties of the Council of Europe, full list of which could be found here https://www.coe.int/en/web/conventions/ search-on-states/-/conventions/treaty/country/1.

3 The judgments in cases of Baka v. Hungary, Kudeshkina v. Russian Federation, Ramos Nunes de Cravalho e Sá (55391/13) and Volkov group of cases (O. Volkov, Kulykov and Others as well as Denisov (GC) judgment) are still pending execution before the Committee of Ministers of the Council of Europe. expressed in the EU Charter of Fundamental Rights, to the European Convention on Human Rights, case-law of the Court as well as the treaty law and soft law developed by the Council of Europe. This commitment is further manifested in the on-going dialogue on accession of the EU to the European Convention on Human Rights, avenue opened for the EU by Protocol No. 14 to the Convention. ${ }^{4}$ Ideally, interaction between the Council of Europe and the European Union should lead to construction of a uniform human rights constitutional legal space, built on the same principles of compliance with rule of law and human rights, a destination that still remains on the horizon (Juncher, 2006).

Similar trends and patterns of overlap in human rights and rule of law dialogue with the member states of the Council of Europe, which are not EU members, could be observed in interaction with states that have aspirations for becoming EU members. In the early 2000s the Council of Europe was seen as a platform preparing states for EU membership in segments of democratic stability, especially stability of institutions ensuring rule of law and human rights protection, notably judiciary and law enforcement. Positive dynamics in these areas in such states as notably Romania, Bulgaria, Poland, Slovenia and most recently Croatia in 2013, led to their accession to the European Union, with most of the preparatory rule of law work done as a part of implementation of accession obligations under the Council of Europe legal instruments. Ukraine, being one of the states in block of Eastern Partnership states, having recognized, as its Constitutional ideal a path to membership in the $\mathrm{EU}$, can gain a lot from carefully studying and considering experiences of these states, both preaccession and post-accession, in order to build its rule of law and human rights policies vis-à-vis the obligations arising not only from the Council of Europe, but also vis-à-vis the European Union.

While the scope of interaction "in the triangle" of the EU, the Council of Europe and member-state in the areas of human rights and rule of law is extensive ${ }^{5}$, the EU and Council of Europe collaborate

\footnotetext{
${ }^{4}$ The accession of the European Union to the Convention denotes the process whereby the European Union will join the community of 47 European states which have entered into a legal undertaking to comply with the Convention and have agreed to supervision of their compliance by the European Court of Human Rights. https://www. echr.coe.int/Pages/home.aspx? $\mathrm{p}=$ basictexts/accessioneu\&c=

5 The Annual Receipts on EU contributions under Joint Programmes between the Council of Europe and the European Union in 2015 , amounted to $€ 25.8$ million, representing a $20 \%$ increase on 2014. These accounted for $49 \%$ of all 2015 income from extrabudgetary contributions, confirming the EU as the major external contributor to $\mathrm{CoE}$ activities. https://www.coe.int/en/web/portal/european-union In addition to that, the Cumulative Budgetary Envelope being implemented in 2017 reached $€ 146.5$ million
} 
mainly via "geographic cooperation" and "thematic cooperation" (human rights, democracy and the rule of law as well as the cross-cutting issues). In this article I will try to focus exclusively on the principles of the case-law of the Court in relation to assessment of EU law, which are seen as important from the point of view understanding interaction between these two legal regimes, which, even though are based on the same values, have a difference in approaches to assessment of compliance with main human rights standards. I will try to underline the main issues and will attempt to relate the case-law issues to a situation of Ukraine, as non-EU member state, but at the same time Association Treaty contracting party, and to project the main areas of concern that could require resolving for the Ukrainian authorities in their attempt to become a full-fledged EU member. In examples I will give, as regards other states, this paper will mostly focus on the human rights compliance from the point of view of rule of law adherence, based on access to an efficient and independent judicial system. To begin with, I will first briefly focus on the role of the Copenhagen criteria played in this process and relate it to the process of execution of judgments. I will try to relate these processes to the processes concerning Ukraine. I will then conclude on the importance of building a strategic roadmap for admission to the EU, through the primary need to ensure compliance with the Council of Europe human rights and rule of law obligations, including execution of judgments of the European Court of Human Rights, without which accession to the EU appears impossible.

As regards Copenhagen criteria and the need to strengthen implementation of the Convention at the domestic level

To begin a brief discussion on the Copenhagen criteria one might wish to look into the most recently adopted policy papers of the EU on the issues related to its external policies on human rights (some of which could be also seen as internal vis-à-vis EU Member States). Most remarkably, under the most recent Council Conclusions on EU Priorities in UN Human Rights For a in 2020, the EU will continue calling on all states to accede to core human rights treaties and will aim at their full implementation at the national level as well as will reject any attempts to redefine human rights in international law and

$(€ 145.9$ million in 2016) of which the EU's contribution amounted to $€ 124.3$ million $(84.8 \%$ ), and that of the Council of Europe to $€ 22.2$ million (15.2\%). https://eeas.europa.eu/delegations/councileurope/1837/council-europe-and-eu_en international human rights standards and to undermine the international rules-based order (Council Conclusions, 2020). Such approach is fully aligned with the Treaty of Lisbon, which sets out the obligations for member states to (a) to respect fundamental rights within the European Union and (b) to advance and consolidate human rights in EU external action. Furthermore, the Council of EU is under an obligation to make sure that fundamental rights are taken into account when developing EU legislation and action, human rights are promoted in relations with non-EU countries and international institutions, as well as in the negotiation of international agreements. ${ }^{6}$

Separately, with regard to accession criteria, or so-called "Copenhagen criteria", known by that geographic indicator because they were defined by the European Council in Copenhagen in 1993 (Presidency conclusions, 1993), these are: political, economic, administrative and institutional capacity criteria. As to the "political criteria" they are being defined as "stability of institutions guaranteeing democracy, the rule of law, human rights and respect for and protection of minorities". In turn, economic criteria relate to "a functioning market economy and the capacity to cope with competition and market forces". Finally, the third criteria - administrative and institutional capacity to effectively implement the acquis communautaire and ability to take on the obligations of membership. ${ }^{7}$ It is interesting to note that assessment of compliance with "respect and protection of national minorities" was partly based on work undertaken by the Council of Europe in its monitoring over compliance with obligations under the Council's Convention on protection of national minorities. "Geographical criteria", i.e. being a European state and compliance with acquis communautaire were also not to be overlooked (Legal questions, 1998). In any case, for the EU accession negotiations to be launched, a country must satisfy the political criterion for accession. A particular, step in preparing accession to the EU is a "pre-accession strategy", which offers a "structured dialogue" between EU institutions and candidate enlargement countries, with the aim of fulfilling Copenhagen criteria (Pre-accession strategy, n.d.).

${ }^{6}$ Protection and promotion of human rights (information page) via three main tools Annual report on application of the EU Charter of Fundamental Rights, operation of the Fundamental Rights Agency and ensuring compliance with human rights standards with legislative process. Additionally, work on Accession to the European Convention on Human Rights is seen as a major future step forward in establishing operation of a common legal space in Europe: https://www.consilium.europa.eu/en/policies/human-rights/

In addition to the above, it is for the EU to decide whether the country is ready to join it and whether the EU has capacity to "absorb" a new Member-State. 
It is being frequently argued that the scope of the Copenhagen criteria is inherently vague. However, in context of specific meaning to be given to political criteria, through more specific standards of the rule of law, human rights and protection of national minorities, which one can see in the standard setting and monitoring work of the Council of Europe, these visibly vague criteria attain specific legal meaning and gain substance. For instance, Venice Commission adopted clear guidelines as to rule of law compliance - Venice Commission Rule of Law Checklist (Rule of Law Checklist, 2016). The European Court of Human Rights and the Committee of Ministers of the Council of Europe give very clear and unequivocal reactions to specific human rights issues in the Court's judgments and in the decisions of the Committee of Ministers supervising human rights compliance with the judgments of the Strasbourg Court. Thus, these are very clear rule of law and human rights compliance indicators stemming from the work of these human rights monitoring and standard setting institutions. For instance, in pre-accession dialogue concerning Turkey, the EU Pre-Accession Report of 2001 pays particular attention to the judgments of the Strasbourg Court and their enforcement:

"...As regards judgements of the European Court of Human Rights, measures need to be incorporated into Turkey's legislation to make reparation for the consequences of convictions that have been found contrary to the European Convention on Human Rights (ECHR). This was stressed in Interim Resolution (2001) 106 adopted by the Council of Europe's Committee of Ministers on 23 July 2001. There is still no possibility under the Code of Criminal Procedure to reopen impugned proceedings or to take any other action to redress violations of the Convention. Other measures are required to ensure the restoration of civil and political rights, where those rights have been restricted as a result of a conviction, the reopening of proceedings and the clearing of criminal records. The ruling of the European Court on Human Rights of 17 July 20013 highlights the issue of how the absence of a fair trial can be compensated. The Constitutional amendments to Article 36 makes explicit the right to a fair trial and paves the way for the necessary legislative changes in the Codes on Criminal, Legal and Administrative corruption. There also remains the problem of direct effect of ECHR judgements (the Constitutional reform package did not tackle any of these issues). ..." (Regular Report on Turkey, 2001)

Most recently, Turkish authorities reported in several cases that the execution measures were a part of the work of the Reform Action Group, whose task was to elaborate strategies as regards the EU accession (Updated information on Oya Otaman $v$. Turkey, 2019).

To ensure compliance with rule of law and human rights, the EU frequently provides assistance, normally via the so-called "instruments of pre-accession assistance", to the states in meeting the compliance targets with the Copenhagen criteria. ${ }^{8}$ Such assistance does not necessarily lead to immediate improvements in target areas as for instance for independence of the judiciary (EU preaccession assistance, 2018). Provided guidance and assistance also requires solid and coherent action on the part of the domestic authorities and not only commitment to undertake action. In any case, even after the launch of accession negotiations and success in pre-accession targets of Copenhagen criteria, a candidate country, needs to undergo meticulous screening of compliance with EU acquis communautaire based on more than 30 policy chapters. The accession negotiations follow the logic of these chapters. Several of these chapters concern fundamental rights and rule of law elements. For instance, Chapter 23 clearly focuses on "judiciary and fundamental rights" (Chapters, 2019). This Chapter clearly speaks about the need to ensure functioning of "independent and efficient judiciary" and the need to ensure "impartiality, integrity and a high standard of adjudication by the courts for safeguarding the rule of law". It asks for "firm commitment to eliminating external influences over the judiciary and to devoting adequate financial resources and training". Overall, the Chapter elaborates on the need for a candidate state to ensure that "legal guarantees for fair trial procedures" are put in place.

Only upon completion of screening of each of the chapters, the EU Parliament could give its consent and the Council might give unanimous approval that the accession treaty could be signed and then submitted by all contracting states for further ratification. Nevertheless, monitoring for compliance does not stop even after accession as the EU could closely monitor compliance with key areas of previous concern, which could be notably issues related to judicial reform or anti-corruption measures. ${ }^{9}$ A monitoring process is based on the need to ensure fundamental compliance with rule of law, aiming to address structural weaknesses in the countries concerned, in particular in the area of the

\footnotetext{
${ }^{8}$ More information on the instruments of pre-accession assistance: https://ec.europa.eu/neighbourhood-enlargement/instruments/ overview_en.

9 This was the case for such countries as Bulgaria and Romania, whose compliance with judicial reform measures and anti-corruption measures was being monitored.
} 
fundamentals required for accession (Enhancing the accession, 2020), such as firm rule of law compliance or independence of judiciary.

An example of Croatia's accession to the EU in 2013 can probably be illustrated by an assessment of the EU on the state of interaction with the European Court of Human Rights:

\begin{abstract}
"...During the reporting period, the European Court of Human Rights (ECtHR) delivered 22 judgments finding that Croatia had violated rights guaranteed by the European Convention on Human Rights (ECHR). A total of 987 new applications were allocated to ECtHR decision bodies since October 2010. In September 2011, a total of 1,726 allocated applications regarding Croatia were pending before the ECtHR. Cases continued to mainly concern the length of proceedings claims, under Article 6 of the Convention. Most of those cases were concluded by an amicable settlement between the government and applicants. The Court also found violations of Article 8 (right to respect for private and family life), Article 46 (binding force and execution of judgements) and article 14 (prohibition of discrimination) in conjunction with article 9 (right to freedom of thought, conscience and religion). In the case of the disappearance of a person of Serbian ethnicity taken by the Croatian police to the premises of a local police station in late 1991, the Court found a violation of Article 2 of the ECHR (right to life). As regards promotion and enforcement of human rights, Croatia has continued to take various steps to raise public awareness and improve the protection of human rights. Measures to raise awareness of police, prosecutors and courts about human rights law are ongoing. However, enforcement of rights requires continued attention, including in terms of judicial efficiency and access to justice. ..." (Commission Staff Working Paper, 2011)
\end{abstract}

In order to reach the status of an EU member, Croatia took a long path through applying to membership in 2003, taking part in accession negotiations, for some 6 years, from 2005 until 2011 , with the accession treaty signed that year and the country becoming an EU member in July $2013 .^{10}$ For Croatia, the process of supervision over execution of judgments was interlinked with the EU accession process, where Croatia was suggesting that adoption of new legislation, like in the case of Mader, was a part of EU accession requirements (Communication from Croatia, 2012a). Similarly, in the case of Skendzic and Krznaric and Jularic

${ }^{10}$ It is interesting to note in this respect that in the course of the period from 2003 to 2011, Croatia took a number of execution measures under the judgments of the European Court of Human Rights, actively seeking closure of cases by the Committee of Ministers of the Council of Europe, a body composed of a number of EU member states. Such closures could be perceived as indicators of progress in several areas of alignment with acquis communitaire. against Croatia, the Croatian authorities undertook specific obligations regarding investigation and processing of war crimes, and set implementation goals in that direction. Later they have reported to the Committee of Ministers on the results of monitoring by the EU on the most recent developments and progress in implementation of their strategy against impunity for war crimes (Communication from Croatia, 2012b).

Similar situation appeared in the process of execution of judgments of the Strasbourg Court concerning Romania, whereas the accession of Romania to the EU changed, in some areas, the legal landscape with regard to jurisdiction and the recognition and enforcement of judgments in civil and commercial matters. In particular, it led to filling up the legislative gap identified in the judgment of the European Court of Human Rights in a case against Romania. The entry into force of the Council Regulations (EC) No. 44/2001, as from 1 January 2007, directly binding in Romania, partly resolved general measures required in that case (Communication from Romania, 2017).

Difficult situation with regard to execution of judgments concerning Ukraine - a much required change

From the moment of accession of Ukraine to the Council of Europe, Ukraine has taken a number of steps towards building Council of Europe - compliant legal space, having notably adopted a number of crucial legal acts, including Constitution, acts on legal and judicial reforms, judiciary, prosecution service, substantive and procedural codes (Opinion 190, 1995). ${ }^{11}$ Similarly, to these Council of Europe accession promises, some of which are still pending implementation via the obligation to comply with the European Convention on Human Rights and the case-law of the Court, Ukraine is under quite similar Ukraine-EU Association Treaty obligations, for instance, to ensure rule of law, independence and efficiency of judiciary and respect to human rights and fundamental freedoms (Ukraine-EU Association Treaty, 2017). Both EU and Ukraine acknowledged

${ }^{11}$ It has partly dealt with reforms in the role and functions of the Prosecutor's Office, has changed the responsibility for the prison administration and for the execution of judgments to the Ministry of Justice. Fundamental reforms were undertaken in attempts to ensure that independence of the judiciary is in conformity with the Council of Europe standards, notably on the appointment and tenure of judges, with the professional association of judges involved in the procedure for the appointment of judges; the status of the legal profession will be protected by law and a professional bar association will be established. Application to membership of Ukraine to the Council of Europe. Opinion 190 (1995). assembly.coe.int. http:// as sembly.coe.int/nw/xml/XRef/Xref-XML2HTML-en. asp?fileid=13929 (Last accessed 7 June 2020). 
that since the conclusion of the Association Treaty some progress has been achieved in implementing justice sector reforms and renewing the judicial system, even though the reform is still being deemed incomplete (Final Statement and Recommendations, 2019). Similar statement is probably true as regards the assessment of the state of judicial reform by the Council of Europe.

Similar topics, of systemic and structural nature, notably issues related to access to justice, justice efficiency and independence of judges, appear pending execution before the Committee of Ministers of the Council of Europe. They are a part of execution measures in the Oleksandr Volkov group of cases, which also encompasses such judgments of the Strasbourg Court as Denisov and Kulykov and Others (Oleksandr Volkov v. Ukraine, 2013). ${ }^{12}$ These topical issues related to functioning of the justice system appear to be on the agenda on the Court and of the Committee of Ministers almost since the moment Ukraine joined the Council of Europe and became a Contracting Party to the Convention. For instance, a structural and systemic problem of non-execution of judgments appears to be unresolved since 2001, with the first case appearing in the list of cases examined by the Court in 1998 (Burmych and Others v. Ukraine, 2017). ${ }^{13}$ Similarly, the cases of Merit and Svitlana Naumenko concern issues of efficiency of justice that were never fully resolved by the Ukrainian authorities since, in principle, the first cases arriving to the Court in the period between 1998 and 2001. Most recently, in December 2020, the Committee of Ministers observed that, bearing in mind that the first judgment in this group was delivered over 15 years ago, it is essential that the Ukrainian authorities now demonstrate a strong and firm commitment involving the newly-elected key political actors at the highest level, to resolve the issue of the length of proceedings and effective remedies, in order to fulfil their obligations under the Convention (Merit v. Ukraine, 2004). ${ }^{14}$ Non-resolution of the three issues mentioned above, without going into details as regards the

12 See, for more details on the execution measures, especially general measures in the case of Volkov (most recent decisions of the CM of 3-5 March 2020, 1369th meeting). hudoc.exec.coe.int. http:// hudoc.exec.coe.int/ENG?i=004-31281 (Last accessed 7 June 2020).

13 The first case appearing on the agenda concerning nonexecution of the domestic judgments was Kaysyn and Others $v$. Ukraine. This cases was never fully resolved and resulted in a pilot judgment procedure in the case of Yuriy Nikolayevich Ivanov and the examination of compliance issues in the Burmych and Others (GC) judgment (decisions of the CM, 3 March 2020, 1369th meeting). hudoc.exec.coe.int. http://hudoc.exec.coe.int/ENG?i=00447973 (Last accessed 7 June 2020).

${ }_{14}$ See, Merit and Svitlana Naumenko v. Ukraine, status of execution and notes as well as CM decisions from the last meeting in December 2019. hudoc.exec.coe.int. http://hudoc.exec.coe.int/ ENG?i=004-31316 (Last accessed 7 June 2020). remaining more than 120 leading cases concerning complex, frequently systemic and structural problems identified by the judgments of the Court, among almost 580 judgments pending execution and thus pending supervision over execution by the Committee of Ministers are surely a negative indicator as to compliance with both the Convention, case-law of the Court, soft law of and Council of Europe recommendations. However, non-compliance with such judgments, in essence, also appears to be contrary to obligations under the EU-Ukraine Association Treaty, read in the light of Lisbon Treaty and EU Charter of Fundamental Rights, and would surely be an obstacle in establishing firm compliance with the Copenhagen accession criteria, even further on, with acquis compliance at a possible postaccession phase. Such a premise is also based on the case-law of the Court concerning EU and the issues of "equivalent protection".

\section{Case-law of the Court concerning $E U$ and the issue of "equivalent protection" 15}

Early case-law of the Commission recognized the prevalence of the European Convention of Human Rights over later concluded obligations in the same area under the EU law, underlining that the guarantees of the European Convention on Human Rights affected "the public order of Europe" (Austria v. Italy, 1961). Further on, the case-law of the Court developed a principle that the European Communities should guarantee protection of fundamental rights at a level equivalent to that provided by the Convention $(M \&$ Co. v. Federal Republic of Germany, 1990). Thus, at later stages, in principle the Strasbourg Court stated that it had jurisdiction over measures taken by the States in giving effect to the Community law (Cantoni $v$. France, 1996). In particular, the Court ruled that the respondent State had a wide margin of appreciation in applying Community law and could therefore have been held responsible for a breach of the

15 For a more extensive selection of cases relating to the case-law of the Court concerning EU, see Jurisprudence Factsheet "Case-law concerning the European Union", with more detail information summaries of judgments and decisions adopted by the Court, as updated on 20 February 2020, https://www.echr. coe.int/Documents/FS_European_Union_ENG.pdf. The factsheet underlines that: "To date, the European Union (EU) is not yet a Party to the European Convention on Human Rights. Accordingly, its acts cannot as such be the subject of applications to the European Court of Human Rights (the Court). Nevertheless, issues relating to Community law have been raised regularly with the Court and the former European Commission of Human Rights". Information on cases below is based on the Factsheet, legal summaries of cases and individually summarized judgments and decisions themselves, as based on the list appearing in the Factsheet. More detailed information on cases can be found in HUDOC database of the ECtHR (https://hudoc.echr.coe.int/). 
Convention (ibid.). Further on, in the context of elections to the EU Parliament, the Court reiterated that the European Convention on Human Rights did not exclude the transfer of competences to international organisations provided that Convention rights continued to be "secured". Member States" responsibility therefore continued even after such a transfer, including in matters of elections (in this case possibility to take part in the elections in Gibraltar) (Matthews v. the United Kingdom, 1999). Eventually, as regards complaints on measures taken to give effect to Community law, where the State had no margin of appreciation in taking such measures, the EU law having supranational and binding legal force, the Court took the view that where a state merely complies with its legal obligations flowing from membership of the European Community, "the protection of fundamental rights by Community law [is] ... "equivalent" ... to that of the Convention system", i.e. the principle of proportionality is automatically inherent in such measures. Thus, the Court finally developed the principle of "presumption" of compliance with the Convention in Community law (“Bosphorus Airways" v. Ireland, 2005).

These jurisprudential principles were briefly summarised in the case of Michaud in the following manner:

"102. The Court reiterates that absolving the Contracting States completely from their Convention responsibility where they were simply complying with their obligations as members of an international organisation to which they had transferred a part of their sovereignty would be incompatible with the purpose and object of the Convention: the guarantees of the Convention could be limited or excluded at will, thereby depriving it of its peremptory character and undermining the practical and effective nature of its safeguards. In other words, the States remain responsible under the Convention for the measures they take to comply with their international legal obligations, even when those obligations stem from their membership of an international organisation to which they have transferred part of their sovereignty (see Bosphorus, cited above, $\S 154$ ).

103. It is true, however, that the Court has also held that action taken in compliance with such obligations is justified where the relevant organisation protects fundamental rights, as regards both the substantive guarantees offered and the mechanisms controlling their observance, in a manner which can be considered at least equivalent that is to say not identical but 'comparable' - to that for which the Convention provides (it being understood that any such finding of 'equivalence' could not be final and would be susceptible to review in the light of any relevant change in fundamental rights protection). If such equivalent protection is considered to be provided by the organisation, the presumption will be that a State has not departed from the requirements of the Convention when it does no more than implement legal obligations flowing from its membership of the organisation.

However, a State will be fully responsible under the Convention for all acts falling outside its strict international legal obligations, notably where it has exercised State discretion (see M.S.S. v. Belgium and Greece, cited above, §338). In addition, any such presumption can be rebutted if, in the circumstances of a particular case, it is considered that the protection of Convention rights was manifestly deficient. In such cases, the interest of international cooperation would be outweighed by the Convention's role as a 'constitutional instrument of European public order' in the field of human rights (see Bosphorus, cited above, $\S \S 152-58$, and also, among other authorities, M.S.S. v. Belgium and Greece, cited above, $\S \S 338-40$ ).

104. This presumption of equivalent protection is intended, in particular, to ensure that a State Party is not faced with a dilemma when it is obliged to rely on the legal obligations incumbent on it as a result of its membership of an international organisation which is not party to the Convention and to which it has transferred part of its sovereignty, in order to justify its actions or omissions arising from such membership vis-à-vis the Convention. It also serves to determine in which cases the Court may, in the interests of international cooperation, reduce the intensity of its supervisory role, as conferred on it by Article 19 of the Convention, with regard to observance by the States Parties of their engagements arising from the Convention. It follows from these aims that the Court will accept such an arrangement only where the rights and safeguards it protects are given protection comparable to that afforded by the Court itself. Failing that, the State would escape all international review of the compatibility of its actions with its Convention commitments."

At a later stage, in context of execution of national court's judgments ordering return of a child, the Court examined whether Austrian courts could be presumed to have acted in compliance with its Convention obligations, having regard to the fact that the legal order of the European Union secured protection of fundamental rights in a manner equivalent to that provided by the Convention system, with Austrian courts acting on the basis of the preliminary ruling of the Court of Justice of the European Union (Povse v. Austria, 2013). In context of execution of judgments between two EU member states, where a party thought that the judgment should not be enforced in Latvia, in view of the allegedly deficient proceedings in Cyprus, the Court did not consider that the protection of fundamental rights had been manifestly deficient such that the presumption of 
equivalent protection was rebutted and held that there had been no violation of Article $6 \S 1$ (right to a fair trial) of the Convention. In Avotins, the Court underlined that, the Contracting States remain bound, when applying the European Union law (Regulation (EU) No 1215/2012, 2012), by the obligations under the European Convention on Human Rights, to be seen in the light of the principle of inherent in the EU actions "equivalent protection" of rights. In particular, in the Avotins case (Avotins v. Latvia, 2016), the Court ruled as regards the general principles applicable to the case, that:

"...102. In the context of the former "first pillar" of the European Union (see Bosphorus, cited above, $\S 72$ ), the Court held that the protection of fundamental rights afforded by the legal system of the European Union was in principle equivalent to that for which the Convention provided. In arriving at that conclusion it found, firstly, that the European Union offered equivalent protection of the substantive guarantees, observing in that connection that at the relevant time respect for fundamental rights had already been a condition of the lawfulness of Community acts and that the CJEU referred extensively to Convention provisions and to Strasbourg case-law in carrying out its assessment (see Bosphorus, cited above, § 159). This finding has applied a fortiori since 1 December 2009, the date of entry into force of Article 6 (amended) of the TEU, which confers on the Charter of Fundamental Rights of the European Union the same value as the Treaties and gives fundamental rights, as guaranteed by the Convention and as they result from the constitutional traditions common to the member States, the status of general principles of European Union law (see Michaud, cited above, $\S 106$ ).

103. The Court found the substantive protection afforded by EU law to be equivalent taking into account the provisions of Article $52 \S 3$ of the Charter of Fundamental Rights, according to which, in so far as the rights contained in the Charter correspond to rights guaranteed by the Convention, their meaning and scope are the same, without prejudice to the possibility for EU law to provide more extensive protection (see Bosphorus, cited above, § 80). In examining whether, in the case before it, it can still consider that the protection afforded by EU law is equivalent to that for which the Convention provides, the Court is especially mindful of the importance of compliance with the rule laid down in Article $52 \S 3$ of the Charter of Fundamental Rights given that the entry into force of the Treaty of Lisbon (see paragraph 37 above) conferred on the Charter the same legal value as the Treaties.

104. Secondly, the Court has recognised that the mechanism provided for by European Union law for supervising observance of fundamental rights, in so far as its full potential has been deployed, also affords protection comparable to that for which the Convention provides. On this point, the Court has attached considerable importance to the role and powers of the CJEU, despite the fact that individual access to that court is far more limited than access to this Court under Article 34 of the Convention (see Bosphorus, §§160-65, and Michaud, §§ 106-11, both cited above)..."

In a series of judgments on a sensitive topic of illegal migration and admission of migrants, the European Court of Human Rights criticized the system of Dublin II regulations, aimed at deciding on responsibility of EU Member States for examination of asylum applications lodged in one of the Member States by a third country national. The cases of M.S.S. v. Belgium and Greece (2011), Tarakhel v. Switzerland (2014) and A.M.E. v. the Netherlands (2015), related to assessment of structure and overall situation of the reception arrangements for migrants to the countries from where they entered the territory of the European Union. The Court in the case of M.S.S. ruled that the Belgian authorities, in implementing the Dublin II regulations, should have verified that the migrants sent back to Greece, under expulsion orders, would be treated in compliance with the requirements of the Convention. It also held that the receiving country - Greece - did not act to ensure access to asylum procedures and living conditions compatible with human dignity. These cases underline that, even though the EU regulations could prima facie comply with the European Convention on Human Rights, their implementation and measures related to their enforcement should be Conventioncompatible. ${ }^{16}$ A similar approach, notwithstanding the fact that matters of migration, asylum and extradition are traditional areas of state dominance, had been developed in cases concerning the European arrest warrant (Pianese v. Italy and the Netherlands, 2011; Pirozzi v. Belgium, 2018). In particular, the Court held that implementation measures as regards the arrest warrant were not manifestly deficient, not rebutting the presumption of equivalent protection. However, in a different context, with regard to anti-money laundering measures and confidentiality of lawyer-client relations, where a lawyer had to report suspicious activities of his clients, the Court stated that presumption of equivalent protection did not apply (Michaud judgment extracts are cited above) (Michaud v. France, 2012). ${ }^{17}$

\footnotetext{
${ }^{16}$ Lastly, as based on the judgments relating to the asylum procedures and expulsion of migrants in M.S.S. v. Belgium and Greece, the authorities submit that there is a need for revision of the EU asylum system.

${ }^{17}$ See, Michaud v. France, no. 12323/11, judgment of 6 December 2012. hudoc.echr.coe.int. http://hudoc.echr.coe.int/ eng? $\mathrm{i}=001-115377$ (Last accessed 7 June 2020).
} 
The Court's case on requests for the CJEU preliminary rulings is of special interest, in context of potential dialogue of the States with the European Court of Human Rights as regards the advisory opinions, to be lodged by the higher judicial instances of the Convention member-states with the European Court of Human Rights under Protocol No. 16 to the Convention. In such cases, the Court reiterates the necessity to give reasons, based on the applicable law and the exceptions laid down in CJEU case-law, for their refusal to refer a preliminary question on the interpretation of EU law to the CJEU. They should set out their reasons for considering that the question was not relevant, that the provision had already been interpreted by the CJEU, or that the correct application of EU law was so obvious as to leave no scope for reasonable doubt (Dhahbi v. Italy, 2014). The court would not find a breach of the Convention, notably Article $6 \S 1$, in a situation where the German courts' refusal of the referral, which had not appeared arbitrary, had had sufficient reasons (Harisch v. Germany, 2019). The Court's case-law is very firm on that the Convention did not guarantee, as such, any right to have a case referred by a domestic court to the Court of Justice for a preliminary ruling. However, Article $6 \S 1$ required the domestic courts to give reasons for any decision refusing to refer a question for a preliminary ruling, especially where the applicable law allowed for such a refusal only on an exceptional basis. Thus, the circumstances of the case and what was at stake in the proceedings for the applicant company could require a particularly clear explanation for the decision not to refer that company's questions to the CJEU for a preliminary ruling (Sanofi Pasteur $v$. France, 2020).

Several areas of specific concern for the interaction between the Convention and the EU law relate to the right to regulations of social networks and the Internet as well as the right to a safe environment. In a leading case (Delfi AS v. Estonia, $2015)^{18}$ on liability of a news portal for usergenerated comments, the domestic courts had rejected the portal's argument that, under EU Directive 2000/31/EC on Electronic Commerce, its role as an information society service provider or storage host was merely technical, passive and neutral, finding that the portal exercised control over the publication of comments. Even though the

18 See, Delfi $A S$ v. Estonia (GC), no. 64569/09, judgment of 16 June 2015. hudoc.echr.coe.int. http://hudoc.echr.coe.int/ eng? $\mathrm{i}=001-155105$ (Last accessed 7 June 2020). This case is seen as controversial from the point of view of liability of internet providers and social networks services' suppliers. It is suggested to examine separate opinions to the judgment of majority in this case, giving rise to an interesting debate on liability of internet platforms.
Court did not address the issue under the EU law, it examined whether implementation of this EU Directive was foreseeable. As regards the cases on the right to a safe environment, the Court held that compliance with EU regulations on safe environment was an important legal obligation and did not disproportionately influence the applicant's property rights in a business it was involved in (O'Sullivan McCarthy Mussel Development Ltd v. Ireland, 2018). Similarly, in measures to enforce EU environmental regulations domestically, notably payment of vehicle pollution tax in an application of an emergency ordinance, the applicants had to exhaust domestic remedies before applying to the Court (Pop and Others v. Romania, 2019).

As regards execution of these and other judgments above, it is observed that the authorities actions aimed at execution of the above judgments largely relate to ensuring that implementing measures comply with the requirements of "presumption of equivalent protection" and that the domestic legal space allows for easy enforcement of access to notably the preliminary rulings. Thus, in undertaking measures to enforce the judgment in the case in proceedings brought by under the Hague Convention on the Civil Aspects of International Child Abduction, contrary to Article 8 of the Convention, where the domestic courts had failed to give enough consideration to the grave risk of the applicant children being subjected to domestic violence if returned to their father, the EU regulations had to be applied with caution, as mutual trust between Romania and Italy's child-protection authorities under the EU law, that did not mean that the Romanian had been under an obligation to send the children back to an environment where they were at risk, leaving it up to Italy to deal with any abuse if it reoccurred (O.C.I. and Others v. Romania, 2019).$^{19}$ Also, in cases of non-application of disputed EU legislation, where the disputed staff transfer had been the object of a reference for a preliminary ruling before the Court of Justice of the European Union ("CJEU") in the case C-108/2010, the authorities indicated that the disputed legislation is now applied by the national courts on the basis of the interpretation of relevant EU legislation provided by the CJEU (Ivana Scattolon v. Ministero dell'Istruzione, dell'Università e della Ricerca,

19 See O.C.I. and Others v. Romania, no. 49450/17, judgment of 21 May 2019. hudoc.echr.coe.int. http://hudoc.echr.coe.int eng? $\mathrm{i}=001-193069$ (Last accessed 7 June 2020). For further information on the Action Plan by the authorities and description of the execution of the European Court of Human Rights judgment and general measures under it taken, please see: http://hudoc.exec.coe. int/ENG?i=004-52122 
$2011)^{20}$, in a manner that is compliant with the requirements of the Convention, providing numerous examples of decisions of the Court of Cassation delivered between 2012 and 2019 on application of the preliminary rulings of the CJEU. Finally, in the case of Dhabi v. Italy, cited above, which concerned the Difference of treatment for obtaining the family allowance due to nationality, the authorities submitted that even though it was an isolated case, they still amended in any case the law on judges' accountability (indirect) in force since March 20015, which provides for the possibility to apply for compensation in case of an obvious violation of EU law, including in case of violation of the obligation to refer a preliminary ruling to the CJEU (Dhabi v. Italy, 2015). ${ }^{21}$

\section{Concluding remarks}

It appears that the case-law of the Court on interaction between the Convention and the EU legal system is of importance not only from the point of view of understanding interaction between these two legal regimes, but from the point of view of anticipating implementation gaps that might occur in the implementation of EU regulations. There are two main reasons for this argument firstly, the EU law would, in hypothesis, apply directly. However, it would still need certain implementation measures to be taken domestically, to create a legal environment for effective implementation of such measures, i.e. supporting implementation legal acts. In this sense, the second argument relates, to the Ukrainian authorities institutional reaction to international law obligations arising from the Council of Europe obligations and from the measures related to execution of judgments of the Strasbourg Court. In the examples given above, the institutional reaction to systemic and structural problems can be said to show weaknesses in implementation of such institutional and legal measures. Such weaknesses could be repeated and

\footnotetext{
${ }^{20}$ In its judgment of 6 September 2011, the CJEU held that EU law precluded the transferred employees from suffering a substantial loss of salary due to the fact that their length of service in local authorities was not taken into account when determining their salary upon their transfer to the national civil service. The CJEU also found that it was for the national court to examine whether, at the time of transfer, there was a loss of salary. See Ivana Scattolon v. Ministero dell'Istruzione, dell'Università e della Ricerca, no. C108/10, judgment of 11 September 2011, Grand Chamber. curia.europa.eu. http://curia.europa.eu/juris/document/document.jsf?text=\&docid=1 $09144 \&$ pageIndex $=0 \&$ doclang $=E N \&$ mode $=1$ st \&dir $=\& o c c=$ first\&p art $=1 \&$ cid $=3064828$ (Last accessed 7 June 2020).

${ }^{21}$ See Dhahbi v. Italy, no. 17120/09, judgment of 8 April 2014 and the Final Resolution of the Committee of Ministers of the Council of Europe adopted on 17 November 2015, supervision over execution measures closed. hudoc.exec.coe.int. http://hudoc.exec.coe.int/ ENG?i=004-45046 (Last accessed 7 June 2020).
}

replicated from the negative experience on implementation of judgments onwards to experience on implementation of EU law. Indeed, the strength of EU law, in comparison with the varying status of the Convention and the Court's case-law, decisions of the Committee of Ministers as a statutory body of the Council of Europe, is in its supranational nature. Thus, its place in the domestic legal orders of the Member States is much more potent than the one of the Convention, which in some legal systems lacks necessary supporting legislation or sufficient hierarchical recognition, frequently approached from the point of view of conflicts with national constitutional orders. Additionally, "presumption of equivalent protection" means that EU law is in prima facie compliance with the Convention and the Court's case-law, however, in the absence of well-build core domestic rule of law and human rights pillars, the EU legal instruments could suffer from remaining alien implants, far too distant from the unchanged legal system. The distance between the EU law requirements and the reality of the domestic legal system can be too large and this could eventually result in serious implementation gaps or "non-compliance bubbles". Not filling these gaps in advance, by means of ensuring adherence to the core Council of Europe standards, the European Convention on Human Rights requirements, caselaw of the Court, execution measures required by the Committee of Ministers in the process of supervision over execution of judgments, would not advance attempts of the Ukrainian authorities to reach Copenhagen criteria goals. This would, in turn, decrease chances of Ukraine to reach a starting point for accession negotiations, seriously endangering the chances for the EU membership (Amendments, 2019). ${ }^{22}$ In addition and finally, the failure of the authorities to fully resolve these longstanding issues, as standing before the Council of Europe, could lead to serious repercussions based on non-compliance with the statutory obligations of Ukraine before the Council of Europe. Most importantly, the need to resolve these long-standing issues is necessary, in the first place, to Ukraine and its legal system, execution of judgments of the Court

${ }^{22}$ Lastly, these implementation gaps are being addressed in the motion for amendments submitted by an International Trade Committee of the EU Parliament (Amendments 1-23, Draft opinion Markéta Gregorová (PE646.754v01-00), Recommendation to the Council, the Commission and the High Representative of the Union for Foreign Affairs and Security Policy on the Eastern Partnership, in the run-up to the June 2020 Summit (2019/2209(INI)), whereas the Committee suggest to call on the Ukrainian authorities, as EaP countries, to improve the rule of law, guarantee the full respect of human rights and democracy (see the suggested amendments to draft opinion 4). Europarl.europa.eu. https://www.europarl.europa.eu/doceo/document/ INTA-AM-648387_EN.pdf (Last accessed 7 June 2020). 
and ensuring compliance with Copenhagen criteria, being both instruments of revitalising anachronistic legal system of Ukraine and its institutions undergoing important structural reforms, still not fully in line with the tasks of ensuring respect for human rights and the rule of law. The primary task of strengthening the judicial institutions and ensuring respect for human rights and rule of law would permit building bridges between the EU law, Council of Europe standards and domestic legal setting, providing for deep incorporation of these standards into the domestic jurisprudence. In this sense, both the Supreme Court and the Constitutional Court should be institutionally empowered to synchronise interpretation of the domestic law with EU and Council of Europe legal standards. The strategic roadmap for legal integration into the EU should take the above elements into account, as not addressing the potential compliance gaps above, in a timely and coherent manner, could impede potential European integration, preventing wellstructured dialogue on accession to the EU.

\section{References}

A.M.E. v. the Netherlands, no. 51428/10, decision on the admissibility of 13 January 2015. hudoc.echr.coe.int. http://hudoc.echr.coe.int eng? $\mathrm{i}=001-152295$

Accession of the European Union. European Court of Homan Rights. https://www.echr.coe.int/Pages/home.aspx?p=basictexts/ accessioneu\&c=

Amendments 1-23, Draft opinion Markéta Gregorová (PE646.754v 01-00), Recommendation to the Council, the Commission and the High Representative of the Union for Foreign Affairs and Security Policy on the Eastern Partnership, in the run-up to the June 2020 Summit (2019/2209(INI). europarl.europa.eu. https://www.europarl.europa.eu/doceo/document/INTA-AM-648387_EN.pdf

Austria v. Italy, no. 788/60, decision of the Commission of 11 January 1961, Yearbook 4, p. 116.

Avotins v. Latvia, no. 17502/07, judgment (Grand Chamber) of 23 May 2016. hudoc.echr.coe.int. http://hudoc.echr.coe.int/ eng? $\mathrm{i}=001-163114$

“Bosphorus Airways" v. Ireland, no. 45036/98, judgment (Grand Chamber) of 30 June 2005. hudoc.echr.coe.int. http://hudoc.echr. coe.int/eng? $\mathrm{i}=001-69564$

Burmych and Others v. Ukraine. Application no. 46852/13. Date(s) of Judgment: 12/10/2017. Judgment(s) became final: 12/10/2017. Latest Decision: CM/Del/Dec(2020)1369/H46-36.

Cantoni v. France, no. 17862/91, judgment of 15 November 1996 hudoc.echr.coe.int. http://hudoc.echr.coe.int/eng? $\mathrm{i}=001-58068$

Chapters of the acquis. EU Neighbourhood and enlargement policy (updated on 17 April 2019). ec.europa.eu. https://ec.europa.eu/ neighbourhood-enlargement/policy/conditions-membership/ chapters-of-the-acquis en

Commission Staff Working Paper. (2011). Croatia, Progress Report, Brussels, (12.10.2011) SEC(2011) 1200 final, accompanying the document, Enlargement Strategy and Main Challenges 2011-2012. ec.europa.eu. https:/ec.europa.eu/neighbourhood-enlargement/ sites/near/files/pdf/key_documents/2011/package/hr_rapport 2011_en.pdf

Communication from Croatia concerning the case of Mader v. Croatia (2012a). (no. 56185/07, Action Plan of 5 April 2012). hudoc.exec. coe.int. http://hudoc.exec.coe.int/ENG?i=DH-DD(2012)377E

Communication from Croatia concerning the cases of Skendzic and Krznaric and Jularic v. Croatia. (2012b). (nos. 16212/08 and 20106/06, Action Plan of 20 August 2012). hudoc.exec.coe.int http://hudoc.exec.coe.int/ENG?i=DH-DD(2012)735E

Communication from Romania concerning the case of Agache v. Romania. (2017). (no. 35032/09, Final Resolution of 5 July 2017). hudoc.exec.coe.int. http://hudoc.exec.coe.int/ENG?i=004-13399

Communication from the Commission to the European Parliament, the Council, the European Economic and Social Committee and the Committee of Regions. (2020). Enhancing the accession process - A credible EU perspective for the Western Balkans. European Commission, Brussels, 5.2.2020 COM(2020) 57 final, ec.europa.eu. https://ec.europa.eu/neighbourhood-enlargement/ sites/near/files/enlargement-methodology en.pdf
Council Conclusions on EU Priorities in UN Human Rights Fora in 2020 adopted by the Council at its $3747^{\text {th }}$ meeting held on 17 February 2020. consilium.europe.eu. http://data.consilium. europa.eu/doc/document/ST-5982-2020-INIT/en/pdf

Delfi $A S$ v. Estonia $(G C)$, no. 64569/09, judgment of 16 June 2015. hudoc.echr.coe.int. http://hudoc.echr.coe.int/eng?i=001-155105

Dhahbi v. Italy, no. 17120/09, judgments of 8 April 2014. hudoc. echr.coe.int. http://hudoc.echr.coe.int/eng?i=001-142504

Enhancing the accession process - A credible EU perspective for the Western Balkans (2020). European Commission, Brussels, 5.2.2020 COM(2020) 57 final, Communication from the Commission to the European Parliament, the Council, the European Economic and Social Committee and the Committee of Regions. ec.europa.eu. https://ec.europa.eu/neighbourhood-enlargement/sites/near/files/enlargement-methodology en.pdf

EU pre-accession assistance to Turkey: Only limited results so far (2018). European Court of Auditors Special Report (July 2018). op.europa.eu. https://op.europa.eu/webpub/eca/special-reports/ turkey-7-2018/en/

European Commission launches infringement against Poland over measures affecting the judiciary. (2017, July 29). ec.europa.eu. https://ec.europa.eu/commission/presscorner/detail/en/ IP 172205

Final Statement and Recommendations pursuant to Article 467(3) of the Association Agreement. EU-Ukraine Parliamentary Association Committee. (2019). Ninth Meeting 13-14 March 2019 (Strasbourg). europarl.europa.eu. https://www.europarl.europa. eu/cmsdata/162346/9th_PAC_Final_Statement_and_recommendations.pdf

Harisch v. Germany, no. 50053/16, judgment of 11 April 2019. hudoc.echr.coe.int. http://hudoc.echr.coe.int/eng?i=001-192213

Ivana Scattolon v. Ministero dell'Istruzione, dell'Università e della Ricerca, no. C108/10, judgment of 11 September 2011, Grand Chamber. curia.europa.eu. http://curia.europa.eu/ juris/document/document.jsf?text $=\&$ docid=109144\&pageIn $\mathrm{dex}=0 \&$ doclang $=\mathrm{EN} \&$ mode $=1 \mathrm{st} \& \mathrm{dir}=\& \mathrm{occ}=$ first $\&$ part $=1 \& \mathrm{c}$ $\mathrm{id}=3064828$

Juncher, J.-C. (2006, April 11). The Council of Europe - European Union: a sole ambition for the European continent. Report of, the PM of Luxembourg. rm.coe.int. https://rm.coe.int/CoERMPublicCommonSearchServices/DisplayDCTMContent?docum entId $=0900001680597$ b34

Legal questions of enlargement (Briefing No. 23). (1998 May 19, European Parliament). europarl.europa.eu. https://www.europarl.europa.eu/enlargement/briefings/23a2_en.htm

$M$ \& Co. v. Federal Republic of Germany (no. 13258/87), decision of the Commission of 9 January 1990. hudoc.echr.coe.int. h t t p : / / hudoc.echr.coe.int/app/conversion/ pdf $/$ ?library $=$ ECHR\&id $=001-863 \&$ filename $=001-863$.pdf

M.S.S. v. Belgium and Greece, no. 30696/09, judgment (Grand Chamber) of 21 January 2011. hudoc.echr.coe.int. http://hudoc. echr.coe.int/eng? $\mathrm{i}=001-103050$ 
Matthews v. the United Kingdom, no. 24833/94, judgment (Grand Chamber) of 18 February 1999. hudoc.echr.coe.int. http://hudoc. echr.coe.int/eng?i=001-58910

Merit v. Ukraine. Application no. 66561/01. Date(s) of Judgment: 30/03/2004. Judgment(s) became final: 30/06/2004. Latest Decision: CM/Del/Dec(2019)1362/H46-34.

Michaud v. France, no. 12323/11, judgment of 6 December 2012. hudoc.echr.coe.int. http://hudoc.echr.coe.int/eng?i=001-115377

O.C.I. and Others v. Romania, no. 49450/17, judgment of 21 May 2019. hudoc.echr.coe.int. http://hudoc.echr.coe.int/eng? $\mathrm{i}=001-$ 193069

O'Sullivan McCarthy Mussel Development Ltd v. Ireland, no. 44460/16, judgment of 7 June 2018. hudoc.echr.coe.int http://hudoc.echr.coe.int/eng?i=001-183395

Oleksandr Volkov v. Ukraine. Application no. 21722/11. Date(s) of Judgment: 09/01/2013. Judgment(s) became final: 27/05/2013. Latest Decision: CM/Del/Dec(2020)1369/H46-38.

Opinion 190. (1995). Application by Ukraine for membership of the Council of Europe. assembly.coe.int. http://assembly.coe.int/nw/ $\mathrm{xml} / \mathrm{XRef} / \mathrm{Xref}-\mathrm{XML} 2 \mathrm{HTML}-\mathrm{en}$.asp?fileid=13929

Overview - Instruments for Pre-accession Assistance. European Neighbourhood Policy And Enlargement Negotiations. https://ec.europa. eu/neighbourhood-enlargement/instruments/overview_en

Pianese v. Italy and the Netherlands, no. 14929/08, decision on the admissibility of 27 September 2011. hudoc.echr.coe.int. http:/ hudoc.echr.coe.int/eng?i=001-99745

Pirozzi v. Belgium, judgment of 17 April 2018. hudoc.echr.coe.int. http://hudoc.echr.coe.int/eng?i=001-182591

Pop and Others v. Romania, no. 54494/11, 67699/11 and 21251/12, decision on the admissibility of 2 April 2019, Information Note on the Court's case-law 228. hudoc.echr.coe.int. http://hudoc. echr.coe.int/eng? $\mathrm{i}=002-12457$

Povse v. Austria, no. 3890/11, decision on the admissibility of 18 June 2013. hudoc.echr.coe.int. http://hudoc.echr.coe.int/ eng? $\mathrm{i}=001-122449$

Pre-accession strategy. (n.d.). Glossary of summaries (EU-Lex). eur-lex.europa.eu. https://eur-lex.europa.eu/summary/glossary/preaccession_strategy.html
Presidency conclusions. (1993, June 21-22). Copenhagen, European Council. europarl.europa.eu. https:/www.europarl.europa.eu/ enlargement/ec/pdf/cop_en.pdf

Regular Report on Turkey's Progress Towards Accession. (2001). Commission of the EC, Brussels, 13.11.2001 SEC(2001) 1756, 2001. ec.europa.eu. https://ec.europa.eu/neighbourhood-enlargement/sites/near/files/archives/pdf/key_documents/2001/ tu_en.pdf

Regulation (EU) No 1215/2012 of the European Parliament and of the Council of 12 December 2012 on jurisdiction and the recognition and enforcement of judgments in civil and commercial matters. eur-lex.europa.eu. https://eur-lex.europa.eu/legal-content/EN/ ALL/?uri=celex\%3A32012R1215

Rule of Law Checklist, adopted by the Venice Commission at its 106th Plenary Session (Venice, 11-12 March 2016). CDL$\mathrm{AD}(2016) 007-\mathrm{e}$. venice.coe.int.int. https://www.venice.coe.int/ webforms/documents/?pdf=CDL-AD(2016)007-e

Rule of Law: European Commission launches infringement procedure to protect judges in Poland from political control. (2019, April 3). ec.europa.eu. https://ec.europa.eu/commission/presscorner/detail/en/IP_19_1957

Sanofi Pasteur v. France, no. 25137/16, judgment of 13 February 2020. hudoc.echr.coe.int. http://hudoc.echr.coe.int/eng?i=001201432

Spano, R. (2014). Universality or Diversity of Human Rights?: Strasbourg in the Age of Subsidiarity. Human Rights Law Review, 14(3), 487-502. https://doi.org/10.1093/hrlr/ngu021

Tarakhel v. Switzerland, no. 29217/12, judgment (Grand Chamber) of 4 November 2014. hudoc.echr.coe.int. http://hudoc.echr.coe.int/ eng? $\mathrm{i}=001-148070$

Ukraine-EU Association Treaty, Article 14 (Chapter III: Justice, Freedom and Security), last updated 17 October 2017. eu-ua.org. http://eu-ua.org/tekst-uhody-pro-asotsiatsiiu/rozdil-iii-yustytsiiasvoboda-bezpeka

Updated information on Oya Otaman v. Turkey (execution measures). hudoc.exec.coe.int. http://hudoc.exec.coe.int/ENG?i=DH$\mathrm{DD}(2019) 14 \mathrm{E}$

Пушкар П. В.

\section{ПРАКТИКА ЄВРОПЕЙСЬКОГО СУДУ 3 ПРАВ ЛЮДИНИ ТА ПРАВО ЄВРОПЕЙСЬКОГО СОЮЗУ: ПЕРЕХРЕСТЯ ЗНАЧУЩОГО ВЗАЄМНОГО ВПЛИВУ ТА ДІАЛОГУ З МЕТОЮ ПОСИЛЕННЯ ЗАХИСТУ ПРАВ ЛЮДИНИ В ЄВРОПІ}

Діяльність Ради Європи та Європейського Союзу щодо захисту прав людини взаємно доповнює та збагачує ці дві міжнародно-правові системи. Співпраця між двома загальноєвропейськими міжнародними організаціями в галузі прав людини додатково підтверджується підтримкою, яку ЄС надає програмам технічної співпраці Ради Європи, з метою реформування правових систем держав-членів як $\mathrm{CC}$, так і Ради Європи. Політична сталість визнання та стратегічна важливість для Європейського Союзу захисту прав людини, Свропейської конвенції з прав людини, прецедентної практики Свропейського суду з прав людини знайшли вираження і в положеннях Хартії фундаментальних прав СС. Зобов'язання дотримуватися прав людини проявляється і в діалозі, що триває й нині, щодо приєднання $Є С$ до Європейської конвенції з прав людини, ця можливість залишається відкритою для ЄС на підставі Протоколу № 14 до Конвенції. В ідеалі в результаті взаємодії між Радою Європи та Європейським Союзом має утворитися єдиний конституційний правовий простір у галузі прав людини, побудований на принципах дотримання верховенства права та прав людини. Виконання рішень Європейського суду з прав людини є складним правовим, технічним та аполітичним процесом, що може мати незворотні потенційні політичні наслідки, зокрема трансформацію правових систем країн-членів Ради Європи. До того ж країни Східної Європи мають пройти цей етап трансформації в надзвичайно стислі строки. Отже, процес виконання рішень дає додатковий поштовх до зближення правових систем країн-членів Ради Європи, забезпечує інкорпорацію чинних принципів захисту 
прав людини в правові системи Європи, конвергенцію недієвих правових інститутів та їх заміну на дієві інституційні засоби захисту прав людини. Цілком логічним є твердження про те, що стратегічна мета європейської інтеграції та вступу до СС має бути синхронізована та узгоджена з процесом виконання рішень Страсбурзького Суду. Прогрес у виконанні рішень Європейського суду з прав людини, що стосуються системно-структурних проблем, у частині заходів загального характеру, буде значним успіхом у досягненні відповідності стану правової системи України Копенгагенським критеріям приєднання до ЄС.

Ключові слова: Рада Європи, Свропейський Союз, Європейська конвенція з прав людини, Свропейський суд з прав людини, практика Суду, приєднання, європейська інтеграція, виконання рішень, Копенгагенські критерії. 